International Research Journal of Management, IT \& Social Sciences
Available online at https://sloap.org/journals/index.php/irjmis/
Vol. 7 No. 1, January 2020, pages: 116-127
ISSN: 2395-7492
https://doi.org/10.21744/irjmis.v7n1.828

\title{
Profitability and Liquidity on Firm Value and Capital Structure as Intervening Variable
}

Ida Ayu Gede Dika Martami Sari ${ }^{\text {a }}$ Ida Bagus Panji Sedana ${ }^{b}$

\section{Article history:}

Submitted: 18 November 2019

Revised: 27 December 2019

Accepted: 04 January 2020

\section{Keywords:}

capital structure;

firm value;

liquidity;

profitability;

signaling theory;

\begin{abstract}
This study aims to determine the effect of profitability and liquidity on firm value and determine the role of capital structure in mediating the effect of profitability and liquidity on firm value in the construction and building subsector companies listed on the Indonesia Stock Exchange (IDX) for the period 2013-2017. The population in this study are construction and building subsector companies that are listed on the Indonesia Stock Exchange and have complete financial statements for the period 2013-2017. This study uses samples with the census method. The data analysis technique used is path analysis. Profitability has a positive and significant effect on capital structure, Liquidity has a negative and significant effect on capital structure, capital structure has a positive and significant effect on firm value, profitability has a positive and significant effect on firm value, liquidity has a negative and not significant effect on firm value and capital structure is able to mediate the effect of profitability and liquidity on firm value.
\end{abstract}

International research journal of management, IT and social sciences (C) 2020. This is an open access article under the CC BY-NC-ND license (https://creativecommons.org/licenses/by-nc-nd/4.0/).

Corresponding author:

Ida Ayu Gede Dika Martami Sari,

Faculty of Economics and Business, Udayana University, Denpasar, Indonesia.

Email address: idaayudika@gmail.com

a Udayana University, Denpasar, Indonesia

${ }^{\mathrm{b}}$ Udayana University, Denpasar, Indonesia 


\section{Introduction}

Firm value is a picture of a company's performance that can affect an investor's assessment of a company. Firm value can be influenced by several factors, namely the debt policy set by a company, the company's ability to generate profits, the company's ability to manage finances in financing all company obligations, the scale of the company, the company's stock price, income from a company and other factors that have been tested through other empirical research. The aim of the company is to maximize the prosperity of the company owners by maximizing the share price. Maximizing the firm value is an appropriate goal to guide financial management decisions. Maximizing the firm value is to maximize profit or income by taking into account the risk factors and the time value of money (Hamidah et al., 2015). The stock price is a picture of the firm value that is expected to provide positive benefits by shareholders. The company aims to maximize the welfare of shareholders through investment decisions and policies, leverage, and dividend decisions as reflected in share prices on the stock market (Handriani \& Robiyanto, 2018).

Efforts made to achieve this goal are that the majority of shareholders surrender the management responsibilities of the company to professionals called managers. Professional managers appointed by shareholders are expected to act on behalf of the shareholders to maximize the firm value so that the goal for the welfare of shareholders will be achieved (Handriani \& Robiyanto, 2018). Shareholders and investors have an interest in a company's financial statements to obtain information about the financial position, performance, and changes in the financial position of a company. One illustration that the company has good prospects is good financial performance. The financial performance of a company can be assessed based on a series of financial ratio analysis used to interpret the condition of a company's financial performance such as liquidity ratios, asset management ratios, debt management ratios, profit ratios and market value ratios (Hamidah et al., 2015).

The company's goals can be achieved through the proper implementation of financial management functions because every financial decision taken will affect other financial management decisions and will have an impact on the firm value. The optimal combination of three financial management decisions namely investment decisions, funding decisions, and dividend policies can maximize the firm value and each policy or decision taken by the company will be related to one another (Ernayani et al., 2017).

Investment trends in the construction and building sub-sectors in Indonesia are still attractive for investors as business land which is expected to provide large returns. Investment can be defined as the commitment of a number of funds for one or more assets owned in the coming periods (Jones, 2014). The issuers' shares in the construction and building sub-sector are considered to be still liquid, although the index of construction and building sub-sector tends to decline due to the construction and building sub-sector is long-term and grows in line with economic growth in Indonesia. In 2017, the performance of issuers' shares in construction and building sub-sectors experienced a decline, even far behind the performance of the Composite Stock Price Index (CSPI) which increased by 20 percent during 2017. The decline in share prices that occurred in the shares of construction sub-sector issuers and buildings when the construction and building sub-sector company has proven its impressive performance and is accompanied by a very significant profit or profit shows that investors not only see how much profit or profit can be achieved by the construction and building sub-sector companies but also in terms of the company's ability to finance company management.

Factors that influence firm value have been widely debated in various empirical studies. The debate is focused on whether there is an optimal capital structure for a company or whether the level of debt use can increase the firm value (Handriani \& Robiyanto, 2018). Zheng (2017), argues that if the capital structure policy in a company can increase the firm value, then the company must use capital structure decisions to maximize the firm value.

Profitability is an important prerequisite for maintaining the long-term sustainability of a company and is a variable that has a significant effect on the achievement of other company's financial goals. Liquidity has a close relationship with earnings because liquidity indicates the amount of working capital needed by the company to finance the company's operational activities. Planning and supervision of company liquidity are very important for the company because it can avoid the company from the risk of not fulfilling short-term liability financing and excess current assets. One of the company's efforts to improve and maintain company performance is to measure the ability of the capital structure to influence the level of profitability and liquidity of the company so as to increase the firm value. Capital structure is a crucial variable for profitability because an increase in company performance cannot be separated from aspects of corporate capital (Andawastya, 2017). Determination of the right proportion of debt and capital in the capital structure will help the company to increase its profitability (Habib et al., 2016).

Construction and building sub-sector companies are companies that are long-term in nature so that they require large funding to fund the company's operational activities. The debt policy is considered to be one of the sources of

Sari, I. A. G. D. M., \& Sedana, I. B. P. (2020). Profitability and liquidity on firm value and capital structure as intervening variable. International Research Journal of Management, IT and Social Sciences, 7(1), $116-127$. https://doi.org/10.21744/irjmis.v7n1.828 
funding for construction and building sub-sector companies due to a large number of infrastructure projects that require large funding. Hossain \& Hossain (2015), explain that the signaling theory is based on asymmetric information, managers use leverage policies to give signals to the market because investors respond to financing through debt as a sign or signal of high future performance and high corporate cash flow in the future will come. The capital structure is considered to be able to intervene in the effect of profitability and liquidity on the value of the company due to the characteristics of the construction and building sub-sector companies that require large funding in connection with the company's operational financing.

Based on this description, this study aims to examine the direct and indirect effects of profitability, liquidity and capital structure on firm value in the construction and building sub-sector companies listed on the Indonesia Stock Exchange (IDX). Theoretical studies conducted with the study of empirical study findings provide an overview of the variables and the interrelationships between variables which can then help formulate hypotheses. Based on this framework, a thesis study can be expected to be able to provide theoretical and practical contributions related to the direct effect of profitability, liquidity and capital structure on firm value and the indirect effect of profitability and liquidity on firm value through capital structure.

\section{Literature review and hypothesis development}

Hardjito \& Martono (2014), state that Return on Equity shows the power to generate a return on investment based on the book value of shareholders, and is often used in comparing two or more companies in the same industry. Most empirical studies show that there are no consistent theoretical predictions about the effect of profitability on debt policy or corporate leverage (Acaravci, 2015). Andres et al. (2014), explained that the increased debt ratio will send a signal about the profitability of the company and can reduce information asymmetry between managers and investors. The free cash flow theory will suggest that companies with high levels of profit must use more debt to discipline company managers so that the debt policy adopted by the company will encourage them to pay off the debt rather than using company cash or cash to fund inefficient projects (Acaravci, 2015). According to Ramadan (2015), companies that have high profits must borrow more debt to take advantage of the tax on the debt. Research conducted by Fumani \& Moghadam (2015), revealed that there was a positive relationship between profitability proxied through earnings per share and the financial leverage of a company. The model developed by Ross (1977), revealed that the use of debt in a capital structure is a signal delivered by managers to the market (Zeb et al., 2016). Managers will increase the amount of debt used as a more reliable signal because companies that use debt are valued as companies that are confident in the company's prospects in the future and help cash flow in the future.

H1: Profitability has a positive and significant effect on capital structure.

Corporate liquidity is the company's ability to fulfill its short-term obligations on time. Companies that have high profits may not be able to pay dividends to shareholders because there are no funds to pay dividends. Research conducted by Yanti \& Dwirandra (2019), states that there is a positive and significant effect between liquidity and capital structure. A company that is able to meet its financial obligations in a timely manner means that the company is in a liquid state and indicates that the company's opportunity to grow tends to be high. Companies that have a good level of liquidity will easily get additional capital and can maintain the capital structure that the company wants (Pervaiz et al., 2013).

H2: Liquidity has a positive and significant effect on capital structure.

Research Masulis (1983), states that capital structure has a positive and significant effect on firm value. The results of the study are in line with research conducted by Hasbi (2015), which states that capital structure has a positive and significant influence on firm value. Hossain \& Hossain (2015) explain that the signaling theory is based on asymmetric information, managers use leverage policies to give signals to the market because investors respond to financing through debt as a sign or signal of high future performance and high corporate cash flow in the future will come. Modigliani - Miller concluded that the use of debt or leverage will increase the value of the company if the interest costs incurred due to debt can reduce the payment of corporate taxes or tax deductibles (Purwohandoko, 2017).

H3: Capital structure has a positive and significant effect on firm value.

Signaling Theory, Bhattacarya (1979), suggested that high profitability indicates good company prospects so that investors will respond positively and firm value will increase. Increasing dividend payments indicate a better prospect for the company so that investors will respond positively and the firm value will increase. This study supports the 
theory that Moddigliani-Miller revealed that the firm value is determined by the profit from the company's assets. Positive results indicate that the higher the more efficient the turnover of assets or the higher the profit margin obtained by the company so that it will have an impact on increasing firm value. Tahu \& Susilo (2017), states the same thing, profitability has a positive and significant effect on firm value. The results of the study are in line with research conducted by Hasbi (2015), which states that capital structure has a positive and significant influence on firm value. Zuhroh (2019) in his research entitled The Effect of Liquidity, Firm Size and Profitability on The Firm Value with Mediating Leverage revealed that profitability has a positive and significant effect on firm value. The results of Fajaria \& Isnalita (2018), revealed that profitability can significantly increase firm value.

H4: Profitability has a positive and significant effect on firm value.

Liquidity shows the company's ability to meet short-term financial obligations. High liquidity can influence investors to invest in companies so that demand for company shares will increase and cause an increase in stock prices. Liquidity is a serious concern for the company because liquidity plays an important role in the company's success. Research conducted by Farooq \& Masood (2016) revealed that liquidity has a positive and significant effect on firm value. Companies that have good liquidity will be considered to have good performance by investors. This will attract investors to invest their capital in the company. The research results of Cheung et al. (2015) and Tahu \& Susilo (2017), explain that liquidity has a positive effect on firm value which is proxied by Yanti \& Dwirandra (2019), analysis in his study entitled Corporate Liquidity and Firm Value: Evidence From China's Listed Firms explained that there is a positive and significant relationship between liquidity and firm value. The signaling theory states that companies that have a high level of liquidity, then the company can manage the available funds well to maximize the company's operations so that it gets high profits and can pay off short-term debt (Fajaria \& Isnalita, 2018). High profits can be a positive signal for investors so as to increase the firm value (Fajaria \& Isnalita, 2018).

H5: Liquidity has a positive and significant effect on firm value.

Smith \& Watts (1992), revealed that the signaling model predicts that profitable companies will pay large amounts of dividends and have high debt to capital ratios. According to Meggison (1996), in the signaling model of corporate investment, investment can be used as a sign to show the level of corporate profits and reveal that companies that have good prospects will choose to spend large funds for investment so that companies that dare to spend large funds for investment will be valued both by investors. The good assessment given by investors to the company is expected to increase the firm value in the future. Research conducted by Sabrin et al. (2016), proves that profitability has a positive effect on firm value and explains that the high level of profit achievement in a company can justify the existence of dividend payments so that it affects the stock price increase caused by the company's positive signal of its ability to pay dividend.

H6: Profitability indirectly has a significant effect on firm value with capital structure as an intervening variable.

A company that is able to meet its financial obligations in a timely manner means that the company is in a liquid state and indicates that the company's opportunity to grow tends to be high. Companies that have a good level of liquidity will easily get additional capital and can maintain the capital structure that the company wants (Pervaiz et al., 2013). The signaling theory states that companies that have a high level of liquidity, then the company can manage the available funds well to maximize the company's operations so that it gets high profits and can pay off short-term debt (Fajaria \& Isnalita, 2018).

H7: Liquidity indirectly has a significant effect on firm value with capital structure as an intervening variable.

\section{Materials and Methods}

The population in this study are construction and building sub-sector companies listed on the Indonesia Stock Exchange for the study period of 2013 - 2017. Determination of the study sample using the census method. A census is a way of collecting data in which all elements of the population are investigated individually. This study uses path analysis to determine the magnitude of the influence of exogenous variables, namely profitability and liquidity and endogenous variables, namely capital structure and firm value. This study uses path analysis to determine the magnitude of the influence of exogenous variables, namely profitability and liquidity and endogenous variables, namely capital structure and firm value.

Sari, I. A. G. D. M., \& Sedana, I. B. P. (2020). Profitability and liquidity on firm value and capital structure as intervening variable. International Research Journal of Management, IT and Social Sciences, 7(1), 116-127. https://doi.org/10.21744/irjmis.v7n1.828 


\section{Results and Discussions}

The data used in this study are data sourced from the company's annual financial statements for the period of 2013 to 2017. Based on data from the company's annual financial statements, it can be calculated the financial ratios used in this study are profitability ratios (return on assets), liquidity ratio (current ratio), debt ratio (debt to equity ratio) and firm value (price to book value). The results of data tabulation for exogenous and endogenous variables can be presented in full in Table 1.

Table 1

Descriptive statistics

\begin{tabular}{lllll}
\hline Variable & Min & Max & Mean & Std. Deviation \\
\hline Profitability & $-24,28$ & 14,02 & 3,9446 & 5,70477 \\
Liquidity & 1,00 & 2,01 & 1,4286 & 0,21841 \\
Capital Structure & 0,85 & 3,83 & 2,0591 & 0,77118 \\
Firm Value & 0,28 & 5.90 & 2,3071 & 1,26762 \\
\hline
\end{tabular}

Primary Data, 2019

Table 1 shows the average value of the profitability variable in the construction and building sub-sector companies listed on the IDX for the 2013-2017 research period which is proxied by return on assets (ROA) of 3,9446 smaller than the standard deviation value 5, 70477. The standard deviation value of the profitability variable is greater than the average value. This shows that there is a large fluctuation in the profitability variable of the sample company. The average value shows that the average of the construction and building sub-sector companies in Indonesia has a profitability of $394.46 \%$. The high value of return on assets (ROA) shows that in general, the construction and building sub-sector companies in Indonesia have the ability to generate net income from 2013 to 2017.

The profitability variable has a maximum value of 14.2. The maximum value indicates the existence of a construction and building sub-sector company that is able to generate a net profit of $1,420 \%$ of the total assets. The highest ROA ratio throughout the study period was achieved by PT. Surya Semesta Internusa Tbk (SSIA) in 2017. The high ROA ratio is an indicator of the success of PT. Surya Semesta Internusa Tbk (SSIA) in generating net profits in difficult company conditions. The minimum value of -24.28 indicates that there are construction and building subsector companies that are unable to generate net income from the use of company assets. The smallest ROA ratio throughout the study year was achieved by PT. Nusa Construction Engineering Tbk (DGIK) in 2016. PT. Nusa Construction Engineering Tbk (DGIK) suffered a loss of -24.28 times the amount of its assets. PT. Nusa Kontruksi Enjiniring Tbk (DGIK) has a negative value because the amount of net profit is smaller than the total assets of the company. This condition indicates the lack of efficiency and effectiveness of PT. Nusa Kontruksi Enjiniring Tbk (DGIK) in generating net profit.

The mean value of the liquidity variable is proxied by a current ratio of 1.4286 , which is greater than the standard deviation of 0.21841 . The standard deviation value that is smaller than the average value indicates that there are small fluctuations in the liquidity variable data of the construction and building sub-sector companies. The average value indicates that the average construction and building sub-sector company has a current ratio of $142.86 \%$. The high value of the current ratio shows that in general, the construction and building sub-sector companies in Indonesia have a good ability to pay short-term liabilities.

The maximum value of the liquidity variable is 2.01 , indicating that there are companies that have the ability to pay short-term obligations up to $201 \%$. The highest liquidity during the study period was obtained by PT. Surya Semesta Internusa Tbk (SSIA) in 2013. The high current ratio indicates that PT. Surya Semesta Internusa Tbk (SSIA) has a very small amount of short-term liabilities compared to its current assets. The minimum value of the liquidity variable of 1.00 indicates that the construction and building sub-sector companies during the study period have the smallest current ratio of $100 \%$. The current ratio value shows that the construction and building sub-sector company has a sufficient amount of current assets to pay off their current liabilities.

The average value of the mean capital structure variable which is proxied by the debt to equity ratio (DER) is 2.0591 , which is greater than the standard deviation value of 0.77118 . The mean value of the capital structure variable which is greater than the standard deviation value explains that the capital structure variable data has high variability. The average value of the debt to equity ratio (DER) of 2.0591 shows that the average construction and building subsector companies use $205.91 \%$ of debt to finance the purchase of their assets. A high average value indicates that the low level of corporate funding provided by shareholders or the magnitude of the composition of total debt (short-term 
debt and long-term debt) compared to the total own capital of construction and building sub-sector companies. These conditions indicate a balance between the use of external and internal resources by construction and building subsector companies.

The maximum value of the capital structure variable is 3.83, indicating the existence of construction and building sub-sectors that have a debt level of up to $383 \%$, meaning that the company has debt almost up to twice its total equity. The maximum value of the capital structure variable is achieved by PT. Adhi Karya Tbk (ADHI) in 2017. The amount of debt that is greater than the total equity of the company shows the occurrence of negative capital (capital deficiency). The minimum value of the capital structure variable is 0.85 , indicating that there are sample companies that have a minimum debt level of $85 \%$. Construction and building sub-sector companies have very large debts or even more than $50 \%$ using external funding sources to finance the company's operational activities. The lowest debt ratio obtained by PT. Nusa Construction Engineering Tbk (DGIK) in 2014.

The average value (mean) of the firm value variable which is proxied through the price to book value ratio (PBV) is 2.3071 , which is greater than the standard deviation value of 1.26762. The mean value of the firm's value variable is greater than the standard deviation value, explaining that the company's variable value data has high variability. The average value of the price ratio per share to the book value per share or price to book value ratio (PBV) is 2.3071 times indicating that the construction and building sub-sector companies are able to increase the stock price by 2.3071 times compared to book value per share of the company. A high mean value indicates that the higher level of the ability of the construction and building sub-sector companies in creating firm value through high stock prices compared to the book value per share of the company.

The maximum value of the firm value variable is 5.90, meaning that there are construction and building sub-sector companies that are able to increase the stock price by 5.90 times compared to the book value per share of the company. The maximum value is achieved by PT. Waskita Karya Tbk (WSKT) in 2014. The minimum value of the firm value variable is 0.28 , which indicates that there are construction and building sub-sector companies that cannot increase the company's stock price as indicated by the ability of the construction and building sub-sector companies by 0,28 times that is below the value of 1 compared to the book value per share of the company. The minimum value is achieved by PT. Nusa Construction Engineering Tbk (DGIK).

The significance of the direct effect can be known using the t-test. T-test was used to determine the effect of each independent variable on partially dependent variables (Basuki \& Prawoto, 2016). The test criteria are if the significance value of exogenous variables is greater than 0.05 (level of confidence or $\alpha$ of $5 \%$ ) then there is no significant effect of exogenous variables on endogenous variables while if the significance value is less than 0.05 then there is a significant influence of exogenous variables on the endogenous variable.

Table 2

Regression testing results for substructure 1 and substructure 2

\begin{tabular}{llllll}
\hline \multirow{2}{*}{ Effect } & $\begin{array}{l}\text { Standardized } \\
\text { Coefficients }\end{array}$ & $\begin{array}{l}\text { Standard } \\
\text { Error }\end{array}$ & $\mathrm{t}$ & Sig. & Description \\
\cline { 2 - 5 } & Beta & 0,071 & 2,176 & 0,037 & Sig. \\
\hline $\mathrm{X}_{1}-\mathrm{Y}$ & 0,320 & $-2,066$ & $-1,861$ & 0,072 & Not. Sig \\
$\mathrm{X}_{2}-\mathrm{Y}$ & $-0,356$ & 0,663 & 2,253 & 0,031 & Sig. \\
$\mathrm{X}_{3}-\mathrm{Y}$ & 0,403 & 0,018 & 2,463 & 0,019 & Sig. \\
$\mathrm{X}_{1}-\mathrm{X}_{3}$ & 0,328 & 0,470 & $-5,696$ & 0,000 & Sig. \\
$\mathrm{X}_{2}-\mathrm{X}_{3}$ & $-0,759$ & & & & \\
\hline
\end{tabular}

Primary Data, 2019

Error value (e) needs to be calculated to complete the path diagram. This study has two error values (e) namely e1 from regression equation substructure 1 and e 2 from regression equation 2. Structure e1 uses R2 from regression equation substructure 1 and e 2 is calculated using R2 from regression equation substructure 2 . The magnitude of the value $\mathrm{e}_{1}=\sqrt{1-R_{1}^{2}}=\sqrt{1-0,505}=0,7035$ dan $\mathrm{e}_{2}=\sqrt{1-R_{2}^{2}}=\sqrt{1-0,509}=0,7007$.

Sari, I. A. G. D. M., \& Sedana, I. B. P. (2020). Profitability and liquidity on firm value and capital structure as intervening variable. International Research Journal of Management, IT and Social Sciences, 7(1), 116-127. https://doi.org/10.21744/irjmis.v7n1.828 
Table 3

The direct, indirect and total effect

\begin{tabular}{lllc}
\hline Effect & Direct Effect & Indirect Effect Through Capital Structure & Total Effect \\
\hline $\mathrm{X}_{1}-\mathrm{Y}$ & 0,320 & 0,132 & 0,452 \\
$\mathrm{X}_{2}-\mathrm{Y}$ & $-0,356$ & $-0,305$ & $-0,661$ \\
$\mathrm{X}_{3}-\mathrm{Y}$ & 0,403 & - & 0,403 \\
$\mathrm{X}_{1}-\mathrm{X}_{3}$ & 0,328 & - & 0,328 \\
$\mathrm{X}_{2}-\mathrm{X}_{3}$ & $-0,759$ & - & $-0,759$ \\
\hline
\end{tabular}

Primary Data, 2019

Table 3 shows the coefficient of the indirect effect of profitability variables on firm value through the capital structure of 0.132. This explains that indirectly profitability through capital structure has a positive effect on firm value. Based on table 5.9 it can be seen that the coefficient of the indirect effect of liquidity variables on firm value through the capital structure is -0.302 . This indicates that liquidity indirectly through the capital structure has a negative effect on firm value.

In table 3 shows the coefficient of total effect for the relationship between variables. The total effect is calculated by adding up the direct effect and the indirect effect. The coefficient of the effect of total profitability on firm value through the capital structure is 0.452 . The coefficient of influence of total liquidity on firm value through the capital structure is $-0,661$. The coefficient of influence of total profitability, liquidity and capital structure is $0.403,0.328$ and -0.759 , respectively. The coefficient of the total effect is the same as the direct effect because there are no intermediary variables.

Table 3 shows the coefficient of the indirect effect of profitability variables on firm value through the capital structure of 0.132 . This explains that indirectly profitability through capital structure has a positive effect on firm value. Based on table 5.9 it can be seen that the coefficient of the indirect effect of liquidity variables on firm value through the capital structure is -0.302 . This indicates that liquidity indirectly through the capital structure has a negative effect on firm value.

In table 3 shows the coefficient of total effect for the relationship between variables. The total effect is calculated by adding up the direct effect and the indirect effect. The coefficient of the effect of total profitability on firm value through the capital structure is 0.452 . The coefficient of the effect of total liquidity on firm value through the capital structure is $-0,661$. The coefficient of the effect of total profitability, liquidity and capital structure is $0.403,0.328$ and -0.759 , respectively. The coefficient of the total effect is the same as the direct effect because there are no intermediary variables.

Table 4

Sobel test

\begin{tabular}{lll}
\hline Effect & Indirect Effect & Sobel \\
\hline $\mathrm{X}_{1}-\mathrm{Y}$ & 0,132 & 2,2347 \\
$\mathrm{X}_{2}-\mathrm{Y}$ & $-0,305$ & 2,0695 \\
\hline
\end{tabular}

Primary Data, 2019

Table 4 shows the results of the Sobel test. The significance of the indirect effect can be known by comparing the value of Sobel with the value of $\mathrm{Z}$ Table that is equal to 1.96 . Sobel test results indicate a value greater than the value of $\mathrm{Z}$ Table, it shows that the mediating variable is the variable capital structure plays a significant role. Table 4 shows that the profitability and liquidity variables significantly influence the firm value through the capital structure.

\section{Effect of Profitability on Capital Structure}

The path analysis results explain that the profitability variable which is proxied through the ratio of return on assets (ROA) positively and significantly influences the capital structure of the construction and building sub-sector companies listed on the Stock Exchange during the study period of 2013 to 2017. The results of the study support the hypothesis which means that the construction and building sub-sector companies with sufficient profitability ratios can increase the amount of debt. Companies with high profits are considered to have good prospects and thus require a 
larger amount of funds to meet expansion needs so that the use of the amount of debt will increase. Andres et al. (2014), explained that the increased debt ratio will send a signal about the profitability of the company and can reduce information asymmetry between managers and investors.

\section{Effect of Liquidity on Capital Structure}

The coefficient of direct influence in the path analysis shows that the liquidity of the construction and building subsector companies has a negative and significant effect on the capital structure of the construction and building subsector companies listed on the Stock Exchange during the study period of 2013 to 2017. The results of the study are not in line with the research hypothesis. Negative and significant influence indicates that the greater the company's liquidity ratio means the company has internal financing that will be sufficient to pay for its obligations so that the capital structure is also reduced. Companies with a high level of liquidity prefer funding with internal funds. Companies with a high level of liquidity have large internal funds so the company prefers to use its internal funds first before using debt or issuing new shares because paying off current debt will reduce the level of corporate debt. The findings of this study are in line with empirical research conducted by Ghasemi \& Razak (2016), investigating the effect of liquidity on the capital structure of companies listed on the Malaysian Stock Exchange for the period of fiscal 2005 to 2013. This study uses liquidity as an independent variable which is proxied by Quick Ratio and Current Ratio while the capital structure as the dependent variable is proxied through Debt Equity Ratio and Debt Asset Ratio. The results showed that liquidity had a significant effect on all proxies of capital structure. Quick Ratio has a positive effect on leverage while the Current Ratio has a negative effect on leverage.

\section{Effect of Capital Structure on Firm value}

The path analysis results found that the capital structure variable which is proxied by the debt-equity ratio (DER) positively and significantly influences the value of the construction and building sub-sector companies listed on the Stock Exchange during the study period of 2013 to 2017. The results of the study support the hypotheses it means that the construction and building sub-sector companies with an optimal capital structure ratio can increase the firm value. Aggarwal \& Padhan (2017), through their research entitled "Impact of Capital Structure on Firm Value: Evidence from the Indian Hospitality Industry" revealed that there was a significant relationship between leverage and firm value. Research conducted by Osazuwa \& Ayoib (2016); Naseer \& Naseem (2015); and Selcuk (2015), explains that high levels of debt use will give a positive signal to investors because it shows that the company will make some investments that are considered profitable and thus require funding which is quite large and will increase the firm value. According to Ross (1977) in Younus et al. (2014), revealed that managers use the capital structure as a corporate signal to investors. Companies that use debt will signal to investors that cash outflows will be increased in the future so that companies are considered to have attractive options in the near future.

\section{Effect of Profitability on Firm value}

The results of the path analysis found that profitability has a positive and significant effect on firm value for construction and building sub-sectors listed on the Indonesia Stock Exchange during the 2013 study period until 2017. Empirical results of the study support the research hypothesis. Companies that have high profitability, show good prospects of company performance so as to increase firm value. The results of the study are in line with the perspective of signaling theory which states that high profitability shows good company prospects so that investors will respond positively and firm value will increase. Increasing dividend payments indicate a better prospect for the company so that investors will respond positively and the firm value will increase. This study supports the theory that Moddigliani Miller found that the firm value is determined by the profit from the company's assets. Research conducted by Sabrin et al. (2016), proves that profitability has a positive effect on firm value and explains that the high level of profit achievement in a company can justify the existence of dividend payments so that it affects the stock price increase caused by the company's positive signal of its ability to pay dividend. Cheryta et al. (2017), through their research entitled "The Effect of Leverage, Profitability, Information Asymmetry, Firm Size on Cash Holding and Firm Value of Manufacturing Firms Listed at Indonesian Stock Exchange" revealed that profitability has a positive and significant effect on the firm value. Research conducted by Osazuwa \& Ayoib (2016) and Selcuk (2015), explains that the higher the level of profitability of a company, the higher the firm value.

Sari, I. A. G. D. M., \& Sedana, I. B. P. (2020). Profitability and liquidity on firm value and capital structure as intervening variable. International Research Journal of Management, IT and Social Sciences, 7(1), $116-127$. https://doi.org/10.21744/irjmis.v7n1.828 


\section{Effect of Liquidity on Firm value}

The test results in the path analysis found that liquidity has a negative and not significant effect on the value of the construction and building sub-sector companies listed on the Stock Exchange during the 2013 study period until 2017. The results of the study do not support the hypothesis which means the construction and building sub-sector companies are having a liquidity ratio that is too high is also not good because it shows the number of funds that are unemployed so that it can ultimately reduce the company's ability. The insignificant influence means that changes only occur in the liquidity variable and are unable to change or increase the firm value. Koh et al. (2014), explain that a high current ratio means that companies have a lot of funds that are bound in non-productive assets such as excess cash or securities. High current ratios can also be caused by large investment ownership and may become obsolete before being sold so that shareholders do not want high current ratios (Koh et al., 2014). The empirical results of the study are in line with research conducted by Putra \& Sedana (2019), entitled Determinants of Profitability and Firm Value: Evidence from Indonesia Banks which proves that liquidity has a negative and significant effect on firm value. The results of this study are consistent with research conducted by Batten \& Vo (2019), which explains the negative relationship between liquidity and firm value. Zuhroh (2019), in his research entitled The Effect of Liquidity, Firm Size and Profitability on The Firm Value with Mediating Leverage revealed that liquidity has a negative and not significant effect on firm value. Fajaria \& Isnalita (2018), in their study entitled The Effect of Profitability, Liquidity, Leverage and Firm Growth of Firm Value with Its Dividend Policy as A Moderating Variable explains that liquidity has a negative and significant effect on firm value. A high level of liquidity can reduce firm value (Fajaria \& Isnalita, 2018). Companies that have high liquid assets such as cash will be vulnerable to the number of funds that are unemployed so that it can reduce the firm value. Unemployed funds will reduce a company's profits due to the lack of effective and efficient production activities so that returns received by investors in the form of cash dividends will also be reduced (Fajaria \& Isnalita, 2018).

\section{The indirect effect of liquidity on firm value through capital structure}

Table 3 shows that liquidity indirectly through the capital structure has a significant effect on firm value. Capital structure can function as a mediating variable in the effect of liquidity on firm value. Increased liquidity in the construction and building sub-sector companies listed on the IDX can create and increase firm value. Increased liquidity can be used by companies to obtain external funding sources, namely funding from debt. The creditor's confidence in providing funding originating from debt to the company because the creditors considered that the company that has a high level of liquidity will be able to meet its short-term obligations. The liquidity ratio is closely related to the capital structure because the liquidity ratio is one of the ratios of concern to creditors. Construction and building sub-sector companies that have a high level of liquidity ratio will be easier to obtain debt because the creditors will ensure the adequacy of the liquidity ratio first before providing funding in the form of debt to the company. The creditors will ensure the company's ability to pay installment or interest obligations by the company through an evaluation of the adequacy of the liquidity ratio sought by the creditors. Companies that have a high level of liquidity will be able to obtain debt with a high percentage in their capital structure. Construction and building sub-sector companies that have high levels of debt can utilize the debt for investment activities such as the purchase of heavy equipment that can encourage the efficiency of the production process and financial management of the company such as cash reserves to support the company cash flow. Increased efficiency in the production process is expected to reduce production costs so that it will increase the company's profit margins. Companies that obtain a large profit margin can increase the firm value so that it encourages investors to invest their capital in the company shares.

\section{Conclusion}

Based on the results of research that has been done, it can be explained that profitability has a positive and significant impact on firm value. The results of this study have supported several previous empirical studies namely Sabrin $e t$ al. (2016), revealed that profitability has a positive effect on firm value. Based on the results of research that has been done, it can be explained that liquidity has a negative and not significant effect on firm value. Putra \& Sedana (2019) and Fajaria \& Isnalita (2018), state that liquidity has a negative and significant effect on firm value. Batten and Vo (2017) which explains that the negative relationship between liquidity and firm value. Zuhroh (2019), revealed that liquidity has a negative and not significant effect on firm value. Based on the results of research that has been done, it 
can be explained that the capital structure is able to mediate the relationship of profitability and liquidity significantly to the firm value. Capital structure can increase the effect of profitability and liquidity on the firm value. Research conducted by Liang et al. (2014) and Akpinar (2016), found that profitability had a positive effect on the company's capital structure. Research conducted by Ghasemi \& Razak (2016), shows that liquidity has a significant effect on the entire proxy of capital structure.

The results of this study can be used as a guideline in conducting company operational activities. The company is expected to have increasingly large assets so as to increase profitability. A high level of profitability will be able to create high firm value so that it affects the increase in the company's stock price. The company is also expected to manage the company's finances as well as the company's ability to manage its short-term obligations so that the company can fulfill or pay its short-term obligations on time. Companies that have a high level of profitability and liquidity, as well as an optimal capital structure composition, will be able to create good corporate value so that it can affect the survival of the company in the present and the future. The results of this study can be used as a reference for investors to pay attention to the composition of the company's capital structure and the company's ability to function to obtain large profits so that investors can invest their capital in the right company. High firm value is important for investors to determine which companies are targeted for investment and companies that can provide high profit sharing for investors.

\section{Research Limitations}

The limitation of this study lies in the variables studied, namely profitability, liquidity, capital structure and firm value. Research examining the direct effect of profitability, liquidity and capital structure variables on firm value and the indirect effect of profitability and liquidity on firm value through the capital structure as a mediating variable is considered to be replicable.

\section{Conflict of interest statement}

The authors declared that they have no competing interests.

\section{Statement of authorship}

The authors have a responsibility for the conception and design of the study. The authors have approved the final article.

\section{Acknowledgments}

The authors would like to thank the editor of IRJMIS for their valuable time, support and advice in completing the current study

Sari, I. A. G. D. M., \& Sedana, I. B. P. (2020). Profitability and liquidity on firm value and capital structure as intervening variable. International Research Journal of Management, IT and Social Sciences, 7(1), 116-127. https://doi.org/10.21744/irjmis.v7n1.828 


\section{References}

Acaravci, S. K. (2015). The determinants of capital structure: Evidence from the Turkish manufacturing sector. International Journal of Economics and Financial Issues, 5(1), 158-171.

Aggarwal, D., \& Padhan, P. C. (2017). Impact of capital structure on firm value: evidence from Indian Hospitality Industry. Theoretical Economics Letters, 7(04), 982. https://doi.org/10.4236/tel.2017.74067

Akben Selçuk, E. (2015). Corporate diversification and firm value: evidence from emerging markets. International Journal of Emerging Markets, 10(3), 294-310. https://doi.org/10.1108/IJoEM-12-2012-0180

Akpinar, O. (2016). Factors affecting capital structure: a panel data analysis on borsa istanbul. Economic and Social Development: Book of Proceedings, 527.

Andawasatya, R., Indrawati, N. K., \& Aisjah, S. (2017). The effect of growth opportunity, profitability, firm size to firm value through capital structure (study at manufacturing companies listed on the Indonesian stock exchange). Imperial Journal of Interdisciplinary Research, 3(2), 1887-1894.

Andres, C., Cumming, D., Karabiber, T., \& Schweizer, D. (2014). Do markets anticipate capital structure decisions?Feedback effects in equity liquidity. Journal of Corporate Finance, 27, 133-156. https://doi.org/10.1016/j.jcorpfin.2014.02.006

Basuki, A. T., \& Prawoto, N. (2016). Analisis regresi dalam penelitian ekonomi \& bisis (dilengkapi aplikasi SPSS \& eviews).

Batten, J., \& Vo, X. V. (2019). Liquidity and firm value in an emerging market. The Singapore Economic Review, 64(02), 365-376. https://doi.org/10.1142/S0217590817470063

Bhattacharya, S. (1979). Imperfect information, dividend policy, and "the bird in the hand" fallacy. Bell journal of economics, 10(1), 259-270.

Cheryta, A. M., \& Moeljadi, D. N. K. A. (2017). The effect of leverage, profitability, information asymmetry, firm size on cash holding and firm value of manufacturing firms listed at Indonesian Stock Exchange. International Journal of Research in Business Studies and Management, 4(4), 21-31. https://dx.doi.org/10.26905/jkdp.v22i1.1334

Cheung, W. M., Chung, R., \& Fung, S. (2015). The effects of stock liquidity on firm value and corporate governance: Endogeneity and the REIT experiment. Journal of Corporate Finance, 35, 211-231. https://doi.org/10.1016/j.jcorpfin.2015.09.001

Ernayani, R., \& Sari, O. (2017). The effect of return on investment, cash ratio, and debt to total assets towards dividend payout ratio (a study towards manufacturing companies listed in Indonesia stock exchange). Advanced Science Letters, 23(8), 7196-7199. https://doi.org/10.1166/asl.2017.9328

Fajaria, A. Z., \& Isnalita, N. I. D. N. (2018). The Effect of Profitability, Liquidity, Leverage and Firm Growth of Firm Value with its Dividend Policy as a Moderating Variable. International Journal of Managerial Studies and Research (IJMSR), 6(10), 55-69.

Farooq, M. A., \& Masood, A. (2016). Impact of financial leverage on value of firms: Evidence from cement sector of Pakistan. Research Journal of Finance and Accounting, 7(9), 73-77.

Fumani, M., \& Moghadam, A. (2015). The Effect of Capital Structure on Firm Value, The Rate of Return on Equity and Earnings Per Share of Listed Companies in Tehran Stock Exchange. Journal of Finance and Accounting, 6(15).

Ghasemi, M., \& Ab Razak, N. H. (2016). The Impact of Liquidity on the Capital Structure: Evidence from Malaysia. International journal of economics and finance, 8(10), 130-139. http://dx.doi.org/10.5539/ijef.v8n10p130

Habib, H., Khan, F., \& Wazir, M. (2016). Impact of debt on profitability of firms: Evidence from non-financial sector of pakistan. City University Research Journal, 6(01).

Hamidah, H., Iswara, D., \& Mardiyati, U. (2016). The effect of profitability, liquidity, growth sales, operating leverage and tangibility on capital structure (evidence from manufacture firm listed on Indonesia stock exchange in 20112014). JRMSI-Jurnal Riset Manajemen Sains Indonesia, 7(1), 96-116. https://doi.org/10.21009/JRMSI.007.1.06

Handriani, E., \& Robiyanto, R. (2018). Corporate finance and firm value in the Indonesian manufacturing companies. International Research Journal of Business Studies, 11(2), 113-127. https://doi.org/10.21632/irjbs

Harjito, D. A., \& Martono, S. U. (2014). Manajemen Keuangan Edisi Kedua. Yogyakarta: Ekonisia.

Hasbi, H. (2015). Islamic microfinance institution: the capital structure, growth, performance and value of firm in Indonesia. Procedia-Social and Behavioral Sciences, $211, \quad$ 1073-1080. https://doi.org/10.1016/j.sbspro.2015.11.143 
Hossain, I., \& Hossain, A. (2015). Determinants of capital structure and testing of theories: A study on the listed manufacturing companies in Bangladesh. International Journal of Economics and Finance, 7(4), 176-190. https://doi.org/10.5539/ijef.v7n4p176

Jones, C. P. (2010). Investments: Principles and concepts. Wiley.

Koh, A., Ang, S. K., Brigham, E. F., \& Ehrhardt, M. C. (2014). Financial management: theory and practice. Cengage Learning.

Liang, J., Fang Li, L., \& Song, H. S. (2014). An explanation of capital structure of China's listed property firms. Property Management, 32(1), 4-15. https://doi.org/10.1108/PM-02-2013-0012

Masulis, R. W. (1983). The impact of capital structure change on firm value: Some estimates. The journal of finance, 38(1), 107-126. https://doi.org/10.1111/j.1540-6261.1983.tb03629.x

Megginson, D. (1996). Planned and emergent learning: consequences for development. Management learning, 27(4), 411-428. https://doi.org/10.1177\%2F1350507696274002

Naseer, M., \& Naseem, I. (2015). The relationship between working capital management and cash holdings of banks in Pakistan. IUP Journal of Bank Management, 14(2), 7.

Osazuwa, N. P., \& Che-Ahmad, A. (2016). The moderating effect of profitability and leverage on the relationship between eco-efficiency and firm value in publicly traded Malaysian firms. Social Responsibility Journal, 12(2), 295-306. https://doi.org/10.1108/SRJ-03-2015-0034

Pervaiz, Y., Zaman, A., Salam, S. A., \& Bilal, M. (2013). Impact of Liquidity on Capital Structure of Textile Sector of Pakistan. Journal of Economics \& Finance (JEF), 1(6).

Purwohandoko. (2017). "The Influence of Firm's Size, Growth and Profitability of Firm Value with Capital Structure as The Mediator: A Study on The Agricultural Firms Listed in The Indonesian Stock Exchange”. International Journal of Economics and Finance. Vol. 9, No. 8, pp. 103-110. ISSN: 1916-971X. E-ISSN: 1916-9728. Published by Canadian Center of Science and Education.

Putra, I. G. W. R., \& Sedana, I. B. P. (2019). Capital structure as a mediation variable: Profitability and liquidity on company value in real estate companies in Indonesia stock exchange. International Research Journal of Management, IT and Social Sciences, 6(4), 62-72. https://doi.org/10.21744/irjmis.v6n4.640

Ramadan, I. Z. (2015). An empirical investigation of the trade-off theory: Evidence from Jordan. International Business Research, 8(4), 19-24. https://doi.org/10.5539/ibr.v8n4p19

Ross, S. A. (1977). The determination of financial structure: the incentive-signalling approach. The bell journal of economics, 23-40.

Sabrin, A., Sarita, B., Takdir, D., \& Sujono, C. (2016). The effect of profitability on firm value in manufacturing company at Indonesia Stock Exchange. The International Journal of Engineering and Science, 5(10), 81-89.

Smith Jr, C. W., \& Watts, R. L. (1992). The investment opportunity set and corporate financing, dividend, and compensation policies. Journal of financial Economics, 32(3), 263-292. https://doi.org/10.1016/0304405X(92)90029-W

Tahu, G. P., \& Susilo, D. D. B. (2017). Effect of Liquidity, Leverage and profitability to The Firm Value (Dividend Policy as Moderating Variable) in Manufacturing Company of Indonesia Stock Exchange. Research Journal of Finance and Accounting, 8(18), 2222-1697.

Yanti, N. M. Y. W. A., \& Dwirandra, A. (2019). The effect of profitability in income smoothing practice with good corporate governance and dividend of payout ratio as a moderation variable. International Research Journal of Management, IT and Social Sciences, 6(2), 12-21. https://doi.org/10.21744/irjmis.v6n2.601

Younus, S., Ishfaq, K., Usman, M., \& Azeem, M. (2014). Capital structure and financial performance: Evidence from Sugar industry in Karachi Stock Exchange Pakistan. International Journal of Academic Research in Accounting, Finance and Management Sciences, 4(4), 272-279.

Zeb, A., Khan, S., \& Iqbal, M. (2016). Effect of Liquidity and Capital Structure on Financial Performance: Evidence from banking Sector. Significance, 6(7).

Zheng, Y. (2017). Three Essays on Capital Structure and Product Market Interactions.

Zuhroh, I. (2019). The Effects of Liquidity, Firm Size, and Profitability on the Firm Value with Mediating Leverage. KnE Social Sciences, 203-230.

Sari, I. A. G. D. M., \& Sedana, I. B. P. (2020). Profitability and liquidity on firm value and capital structure as intervening variable. International Research Journal of Management, IT and Social Sciences, 7(1), 116-127. https://doi.org/10.21744/irjmis.v7n1.828 